\title{
Analysis of Selected Amino Acids in Different Varieties of Wheat Available in Punjab, Pakistan
}

\author{
Sumera Zafar, ${ }^{1}$ Narjis Naz, ${ }^{1}$ Saliha Nazir, ${ }^{1}$ Mateen Abbas, ${ }^{2}$ and Abdul Muqeet Khan ${ }^{2}$ \\ ${ }^{1}$ Department of Chemistry, Lahore College for Women University, Lahore 54000, Pakistan \\ ${ }^{2}$ Quality Operation Laboratory, University of Veterinary and Animal Sciences, Lahore 54000, Pakistan \\ Correspondence should be addressed to Narjis Naz; narjis107@gmail.com
}

Received 23 May 2014; Revised 29 August 2014; Accepted 22 September 2014; Published 16 October 2014

Academic Editor: Branca Silva

Copyright (c) 2014 Sumera Zafar et al. This is an open access article distributed under the Creative Commons Attribution License, which permits unrestricted use, distribution, and reproduction in any medium, provided the original work is properly cited.

\begin{abstract}
A validated method is proposed to check amino acids variability among eighty-nine wheat samples collected from Punjab province of Pakistan during 2012-2013. Orthophthalaldehyde along with 2-mercaptoethanol was used as a derivatizing reagent that showed florescence at detection wavelength of Ex of $340 \mathrm{~nm}$ and Em of $450 \mathrm{~nm}$ under suitable pH range of 9-10. RPHPLC-FLD system employed was Agilent 1100 series equipped with Eclipse XDB C-18 column $(2.1 \times 150 \mathrm{~mm}, 5 \mu)$ and column temperature was maintained at $40^{\circ} \mathrm{C}$. The maximum concentration of aspartic acid, glutamic acid, leucine, arginine, and histidine was found in Vehari $(0.496 \mathrm{~g} / 100 \mathrm{~g})$, Rajanpur $(1.292 \mathrm{~g} / 100 \mathrm{~g})$, Rahim Yar khan $(0.60 \mathrm{~g} / 100 \mathrm{~g})$, Bahawalpur $(0.662 \mathrm{~g} / 100 \mathrm{~g})$, and Narowal (0.377 g/100 g), respectively, while the minimum in Narowal (0.13 g/100 g), Vehari (0.706 g/100 g), Narowal (0.339 g/100 g), Muzaffargarh $(0.14 \mathrm{~g} / 100 \mathrm{~g})$, and Rahim Yar Khan $(0.088 \mathrm{~g} / 100 \mathrm{~g})$ among the samples obtained from districts. Wheat variety Pb11 contained relatively high aspartic acid $(0.297 \mathrm{~g} / 100 \mathrm{~g})$, glutamic acid $(0.897 \mathrm{~g} / 100 \mathrm{~g})$, and leucine $(0.484 \mathrm{~g} / 100 \mathrm{~g})$ whereas variety Ass-11 had arginine $(0.895 \mathrm{~g} / 100 \mathrm{~g})$ and histidine $(0.266 \mathrm{~g} / 100 \mathrm{~g})$. The amino acids were found to vary as follows: aspartic acid $0.130-$ 0.496 , glutamic acid $0.706-1.292$, leucine $0.321-0.6$, arginine $0.118-0.895$, and histidine $0.088-0.377 \mathrm{~g} / 100 \mathrm{~g}$ flour. The accuracy was in the range of $95.88-100.67 \%$, whereas the RSD for precision was not more than 1.40 for all amino acids.
\end{abstract}

\section{Introduction}

Amino acids are the building block of a major structural and functional component of cell, that is, proteins. Several subunits of amino acids ranging from two to thousand join together through peptide bond and form long chain protein molecules. Proteins provide energy to the body as do carbohydrates, that is, $4 \mathrm{kcal} / \mathrm{g}$ [1]. Amino acids in the diet are required by the body to regulate growth, repair, maintenance, and replacement of tissues. Essential amino acids are required in adequate amounts in the daily diet because these cannot be synthesized in the human body [2]. Histidine was initially considered to be essential only for infants, but now studies have revealed their importance in terms of essentiality for adults too [3]. During limited supply of proper diet, histidine level in the body is maintained by degradation of hemoglobin. The body requirement for histidine by world health organization is between 8 and
$12 \mathrm{mg} / \mathrm{kg}$ per day $[4,5]$. Leucine essentiality lies in the fact that it is utilized in the liver, muscle, and adipose tissues. It helps in the formation of sterols in adipose and muscle tissue. It stimulates the synthesis of muscle protein [6]. Leucine also helps in weight loss by increasing metabolic rate during exercise [7]. The WHO recommended daily dose of leucine is $39 \mathrm{mg} / \mathrm{kg} /$ day [8].

Arginine is a conditionally essential amino acid having biological functions like ammonia detoxification, immune modulation, and hormone secretion [9-11]. Glutamic acid is a dispensable amino acid being synthesized from substances like alpha-ketoglutarate and the other amino acids such as ornithine, proline, arginine, and glutamine. It stimulates neuron activity and plays a significant role in learning and memorizing. According to NHANES III (1988-1994), mean daily intake of glutamic acid is $15 \mathrm{~g} / \mathrm{d}[12,13]$. Aspartic acid, a dispensable acidic amino acid, synthesized from glutamate in the liver, depends on vitamin B6 and is formed by 
the transmission of oxaloacetate. It is also an excitatory neurotransmitter like glutamic acid [14].

Wheat is one of the widely cultivated crops of Pakistan. It is consumed as a staple food as it is a cheap source of carbohydrates and amino acids and minerals and vitamins. Pakistan is an agricultural country and is the 8th largest wheat producer in the world [15].

Pakistan is blessed with agroclimatic regions that are suitable for a wide range of crops. Approximately $70 \%$ of the cultivated wheat is used for making flat bread known as chapatti while the remaining $30 \%$ is used for other purposes like in the formation of bakery items such as bread, cakes, cookies, pastries, pasta, and pancakes. The Punjab province of Pakistan is the main wheat crop producer that contributes to 73 percent of wheat acreage and 78 percent of wheat production [16-19].

The present study encompasses the validation of RPHPLC-FLD method for evaluation of aspartic acid, glutamic acid, leucine, arginine, and histidine contents in wheat grown in different districts of Punjab. This study is also designed to determine amino acid variations among wheat samples and different breeding varieties.

\section{Materials and Methods}

2.1. Chemicals and Reagents. All the amino acids (aspartic acid, glutamic acid, leucine, histidine, and arginine) were obtained from Sigma Chemical Corporation. Orthophthalaldehyde was procured from Uni-Chem. Methanol and acetonitrile (HPLC grade) were obtained from Merck. Hydrated sodium tetraborate was obtained from Riedel-de-Haen, sodium azide from MP Biomedicals, and 2-mercaptoethanol from Merck.

Stock orthophthalaldehyde reagent (OPA) for derivatizing amino acid was prepared by mixing $0.025 \mathrm{~g}$ OPA in $0.5 \mathrm{~mL}$ of methanol and diluting it to $5 \mathrm{~mL}$ with $100 \mathrm{mM} / \mathrm{L}$ borate buffer and to the stock was added $25 \mu \mathrm{L}$ of 2mercaptoethanol. Working OPA was prepared by dilution of stock derivatizing reagent 1000 times with $100 \mathrm{mM} / \mathrm{L}$ borate buffer. Working reagent was prepared freshly on each working day.

$4.75 \mu \mathrm{M} / \mathrm{mL}$ of each amino acid standard was prepared in $0.1 \mathrm{M} \mathrm{HCl}$ and stored at $4^{\circ} \mathrm{C}$. The standard amino acid mixture was prepared by mixing equal amount of amino acid solutions to get $250 \eta \mathrm{M} / \mathrm{mL}$.

2.2. Instrumentation. The gradient HPLC system used was Agilent 1100 series, USA. HPLC instrument was equipped with autoinjector, column compartment, fluorescent detector (G1315B), vacuum degasser, and quaternary pump. Separation was performed on Eclipse XDB C18 Column (ID 2.1 $\times 150 \mathrm{~mm}, 5 \mu$ particle size) at $40^{\circ} \mathrm{C}$. Peak monitoring was achieved on a fluorescent detector with excitation wavelength being $\lambda_{\mathrm{ex}}=340 \mathrm{~nm}$ and emission being $\lambda_{\mathrm{em}}=450 \mathrm{~nm}$.

2.3. Chromatographies Conditions. A number of mobile phases were employed to attain the best resolution of sample components. Mobile phase A consisted of $10 \mathrm{mM} \mathrm{Na}_{2} \mathrm{HPO}_{4}$
TABLE 1: Mobile phase gradient.

\begin{tabular}{lcc}
\hline Time & $\% \mathrm{~A}$ & $\% \mathrm{~B}$ \\
\hline 0.0 & 98.0 & 2.0 \\
5.0 & 98.0 & 2.0 \\
10.0 & 50.0 & 50.0 \\
15.0 & 0.0 & 100 \\
20.0 & 0.0 & 100 \\
23.50 & 98.0 & 2.0 \\
25.0 & 98.0 & 2.0 \\
\hline
\end{tabular}

with $10 \mathrm{mM} \mathrm{Na}_{2} \mathrm{~B}_{4} \mathrm{O}_{7}$ and $5 \mathrm{mM} \mathrm{NaN}_{3}(\mathrm{pH}=8.2)$ while $\mathrm{B}$ consisted of a mixture of $60 \%$ acetonitrile. Mobile phases were prepared freshly and were filtered through $0.45 \mu \mathrm{m}$ filter paper by suction filtration. The flow rate was maintained at $0.5 \mathrm{~mL} / \mathrm{min}$. Excitation wavelength was $340 \mathrm{~nm}$ whereas emission was maintained at $450 \mathrm{~nm}$. The injection volume was $20 \mu \mathrm{L}$ with column temperature of $40^{\circ} \mathrm{C}$ and run time of 25 min. The mobile phase gradient is shown in Table 1 [20].

2.4. Sample Collection. Sixteen districts of Punjab were randomly selected for collection of wheat samples during the year 2012-2013. Five wheat grain samples from each district were collected to get a total of $16 \times 5=80$. Five samples from the tehsil of each district were mixed to get the representative of the corresponding district. Five samples were taken as ration from the local market and four hybrid varieties from Punjab Seed Corporation, Lahore. The names of samples with their abbreviations are explained as follows: NRW = Narowal, GJW = Gujranwala, TTS = Toba Taik Singh, OKR = Okara, HFA = Hafizabad, BWP = Bahawalpur, RYK = Rahim Yar khan, VHR = Vehari, SHW = Sahiwal, DGK = Dera Ghazi Khan, RJP = Rajanpur, KSR = Kasoor, MZG = Muzaffargarh, $\mathrm{PPN}=$ Pakpattan, MLT $=$ Multan, and GJR $=$ Gujrat.

2.5. Sample Preparation and Methodology. The wheat grains were cleaned manually to remove dust and other foreign matter. Grains were packed in a polythene bag under controlled conditions till use. Wheat grains were milled through a grinding machine to get fine flour. The flour was stored in air tight polyethylene bags to avoid any damage till further analysis. Samples were passed through a sieve of $0.5 \mathrm{~mm}$ pore size to get uniform sized particles of flour. Screw capped test tubes were taken for hydrolysis process. They were dipped in $0.1 \mathrm{M} \mathrm{HCl}$ for the whole night to avoid any sort of contamination. Each sample was accurately weighed at about $0.2 \mathrm{~g}$ with the help of analytical balance and was put into test tubes containing $12 \mathrm{~mL}$ of $6 \mathrm{M} \mathrm{HCl}$. Tubes were evacuated by nitrogen flushing and were capped immediately. Tubes containing samples and $\mathrm{HCl}$ were put in an oven for about 24 hours for complete hydrolysis of wheat samples. Samples were taken out from the oven after specified time, cooled to room temperature, and dried to remove $\mathrm{HCl}$. Samples were reconstituted again in $3 \mathrm{~mL}$ of $0.02 \mathrm{M} \mathrm{HCl}$. Each one was filtered carefully through $0.22 \mu \mathrm{m}$ filter paper to remove small sized contaminants prior to centrifugation [21]. 


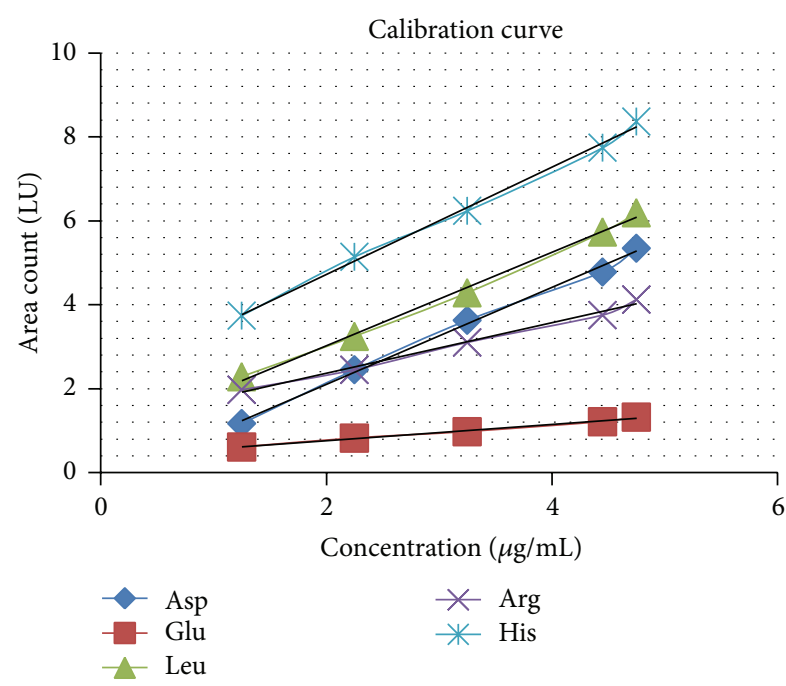

FIGURE 1: Calibration curves for aspartic acid, glutamic acid, leucine, arginine, and histidine.

Protein upon hydrolysis yields its monomers that must be derivatized with some reagent to be detected by fluorescence detector. The derivatizing reagent employed in the present study was orthophthalaldehyde. It reacts with primary amino acids in the presence of 2-mercaptoethanol. The excitation wavelength employed was $\lambda_{\mathrm{ex}}=340 \mathrm{~nm}$ while emission was $\lambda_{\mathrm{em}}=450 \mathrm{~nm}$.

Precolumn derivatization of samples was done manually just before injection into the column. OPA/MCE derivatives were unstable, so samples were prepared freshly and were injected immediately. All samples were filtered through $0.45 \mu \mathrm{m}$ Millipore filtration assembly prior to injection. Each sample was run in triplicate to check the reproducibility of the method. Chromatograms of samples obtained after Integrator, were matched for their retention time with those of the standard amino acid mixture and quantification was achieved mathematically.

2.6. Calibration. Five different concentrations of amino acid solutions were prepared ranging from 1.25 to $4.75 \mu \mathrm{M} / \mathrm{mL}$ to get a calibration curve as shown in Figure 1. The results of calibration are shown in Table 2.

\section{Discussion on Results}

The chromatogram for standard amino acid mixture and a wheat sample after a modified Integrator is shown in Figures 2 and 3, respectively. The retention times of amino acids in sample aliquots were comparable to those of a standard mixture of amino acid and were used for their qualification purpose.

Accuracy of the method was evaluated in terms of recovery by spiking the analyte in blank flour matrices. For precision, six replicates standard solutions of each amino acid were injected and relative standard deviation (\%RSD) was

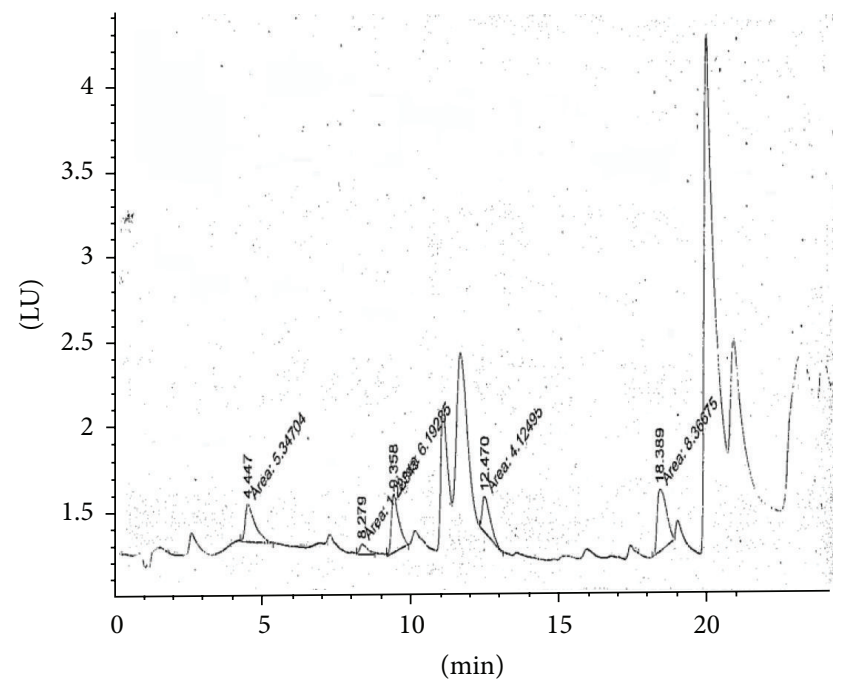

FIgURE 2: Chromatogram of Asp, Glu, Arg, and His with retention time of $4.447,8.279,9.358,12.470$, and 18.389 , respectively.

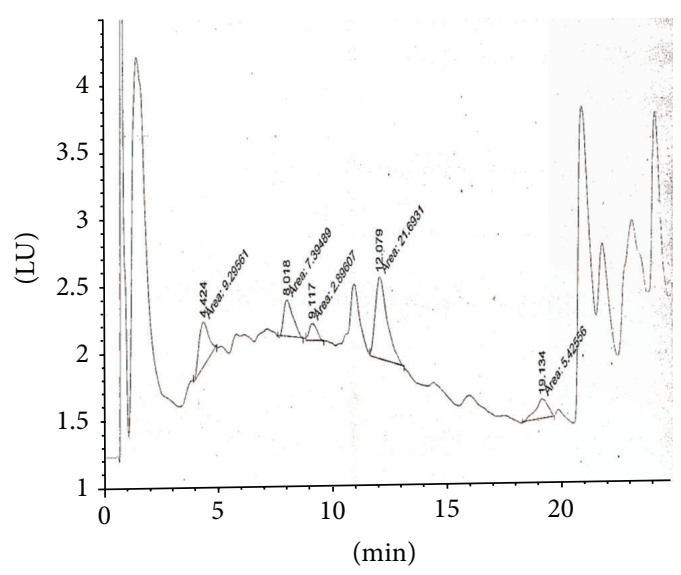

Figure 3: Chromatogram of a wheat sample.

TABLE 2: Calibration curve data for amino acids.

\begin{tabular}{lcccc}
\hline Amino acid & Slope & Intercept & $R^{2}$ & $\begin{array}{c}\text { Regression } \\
\text { equation }\end{array}$ \\
\hline $\begin{array}{l}\text { Aspartic acid } \\
\text { (Asp) }\end{array}$ & 1.153 & 0.202 & 0.996 & $\begin{array}{c}Y= \\
1.153 x+0.202 \\
Y=\end{array}$ \\
$\begin{array}{l}\text { Glutamic } \\
\text { acid (Glu) }\end{array}$ & 0.195 & 0.366 & 0.993 & $\begin{array}{c}Y .195 x+0.366 \\
Y=\end{array}$ \\
$\begin{array}{l}\text { Leucine } \\
\text { (Leu) }\end{array}$ & 1.113 & 0.797 & 0.996 & $\begin{array}{c}Y 113 x+0.797 \\
Y=\end{array}$ \\
$\begin{array}{l}\text { Arginine } \\
\text { (Arg) }\end{array}$ & 0.601 & 1.163 & 0.991 & $\begin{array}{c}Y .601 x+1.163 \\
Y=\end{array}$ \\
$\begin{array}{l}\text { Histidine } \\
\text { (His) }\end{array}$ & 1.278 & 2.168 & 0.996 & \begin{tabular}{c}
$Y .278 x+2.168$ \\
\hline
\end{tabular}
\end{tabular}

calculated. Table 3 represents accuracy and precision data of each amino acid being analyzed.

Limit of detection and quantification were determined on the basis of standard deviation of response and slope obtained from a calibration plot of each amino acid of 
TABLE 3: Accuracy and precision parameters.

\begin{tabular}{|c|c|c|c|c|}
\hline \multirow{2}{*}{ Amino acids } & \multicolumn{2}{|c|}{ Recovery } & \multicolumn{2}{|c|}{ Repeatability } \\
\hline & Mean \pm SD & Recovery \% & Mean \pm SD & RSD \\
\hline Asp & $4.47 \pm 0.055$ & 100.37 & $5.38 \pm 0.065$ & 1.21 \\
\hline Glu & $4.41 \pm 0.030$ & 99.10 & $1.32 \pm 0.017$ & 1.33 \\
\hline Leu & $4.27 \pm 0.234$ & 95.88 & $6.20 \pm 0.058$ & 0.94 \\
\hline Arg & $4.45 \pm 0.030$ & 99.92 & $4.22 \pm 0.059$ & 1.40 \\
\hline His & $4.48 \pm 0.053$ & 100.67 & $8.40 \pm 0.190$ & 1.30 \\
\hline
\end{tabular}

TABle 4: Distribution of aspartic acid, glutamic acid, leucine, arginine, and histidine in wheat samples collected from different areas of Pakistan.

\begin{tabular}{|c|c|c|c|c|c|c|c|c|c|c|}
\hline Sample ID. & Asp & $\pm \mathrm{SD}$ & Glu & $\pm \mathrm{SD}$ & Leu & $\pm \mathrm{SD}$ & Arg & $\pm \mathrm{SD}$ & His & $\pm \mathrm{SD}$ \\
\hline NRW & 0.13 & \pm 0.054 & 0.947 & \pm 0.123 & 0.339 & \pm 0.044 & 0.484 & \pm 0.054 & 0.148 & \pm 0.063 \\
\hline GJW & 0.137 & \pm 0.033 & 1.259 & \pm 0.119 & 0.552 & \pm 0.057 & 0.225 & \pm 0.037 & 0.088 & \pm 0.084 \\
\hline TTS & 0.171 & \pm 0.041 & 0.974 & \pm 0.093 & 0.482 & \pm 0.088 & 0.267 & \pm 0.040 & 0.138 & \pm 0.026 \\
\hline OKR & 0.409 & \pm 0.049 & 0.903 & \pm 0.053 & 0.418 & \pm 0.079 & 0.242 & \pm 0.054 & 0.132 & \pm 0.062 \\
\hline HFA & 0.274 & \pm 0.061 & 0.995 & \pm 0.120 & 0.575 & \pm 0.021 & 0.233 & \pm 0.041 & 0.211 & \pm 0.053 \\
\hline BWP & 0.217 & \pm 0.053 & 0.755 & \pm 0.118 & 0.549 & \pm 0.213 & 0.662 & \pm 0.123 & 0.311 & \pm 0.126 \\
\hline RYK & 0.223 & \pm 0.038 & 1.021 & \pm 0.035 & 0.6 & \pm 0.173 & 0.212 & \pm 0.037 & 0.151 & \pm 0.106 \\
\hline VHR & 0.496 & \pm 0.165 & 0.706 & \pm 0.029 & 0.45 & \pm 0.073 & 0.19 & \pm 0.070 & 0.161 & \pm 0.048 \\
\hline SHW & 0.296 & \pm 0.061 & 0.907 & \pm 0.054 & 0.435 & \pm 0.055 & 0.201 & \pm 0.043 & 0.377 & \pm 0.039 \\
\hline DGK & 0.303 & \pm 0.051 & 0.885 & \pm 0.012 & 0.388 & \pm 0.054 & 0.143 & \pm 0.089 & 0.158 & \pm 0.077 \\
\hline RJP & 0.301 & \pm 0.080 & 1.292 & \pm 0.033 & 0.499 & \pm 0.035 & 0.55 & \pm 0.020 & 0.107 & \pm 0.045 \\
\hline KSR & 0.293 & \pm 0.055 & 0.947 & \pm 0.054 & 0.411 & \pm 0.096 & 0.437 & \pm 0.032 & 0.115 & \pm 0.121 \\
\hline MZG & 0.257 & \pm 0.073 & 0.893 & \pm 0.025 & 0.524 & \pm 0.013 & 0.14 & \pm 0.090 & 0.126 & \pm 0.028 \\
\hline PPN & 0.313 & \pm 0.039 & 0.768 & \pm 0.067 & 0.416 & \pm 0.048 & 0.65 & \pm 0.143 & 0.217 & \pm 0.040 \\
\hline MLT & 0.237 & \pm 0.045 & 0.981 & \pm 0.039 & 0.541 & \pm 0.017 & 0.481 & \pm 0.028 & 0.177 & \pm 0.012 \\
\hline GJR & 0.187 & \pm 0.034 & 0.78 & \pm 0.041 & 0.365 & \pm 0.036 & 0.461 & \pm 0.051 & 0.167 & \pm 0.065 \\
\hline Ass-11 & 0.198 & \pm 0.014 & 0.843 & \pm 0.028 & 0.359 & \pm 0.009 & 0.895 & \pm 0.014 & 0.266 & \pm 0.011 \\
\hline Seher-06 & 0.192 & \pm 0.012 & 0.713 & \pm 0.073 & 0.337 & \pm 0.012 & 0.639 & \pm 0.007 & 0.244 & \pm 0.046 \\
\hline FD-08 & 0.182 & \pm 0.0207 & 0.782 & \pm 0.045 & 0.335 & \pm 0.088 & 0.346 & \pm 0.080 & 0.221 & \pm 0.073 \\
\hline $\mathrm{Pb}-11$ & 0.297 & \pm 0.014 & 0.897 & \pm 0.020 & 0.484 & \pm 0.018 & 0.118 & \pm 0.016 & 0.146 & \pm 0.027 \\
\hline Ration & 0.199 & \pm 0.021 & 0.812 & \pm 0.102 & 0.321 & \pm 0.068 & 0.284 & \pm 0.168 & 0.139 & \pm 0.0325 \\
\hline Average & 0.253 & & 0.907 & & 0.446 & & 0.374 & & 0.181 & \\
\hline
\end{tabular}

Asp = aspartic acid, Glu = glutamic acid, Leu = leucine, Arg = arginine, His = histidine, NRW = Narowal, GJW = Gujranwala, TTS = Toba Taik Singh, OKR $=$ Okara, HFA $=$ Hafizabad, BWP $=$ Bahawalpur, RYK $=$ Rahim Yar Khan, VHR = Vehari, SHW $=$ Sahiwal, DGK $=$ Dera Ghazi Khan, RJP $=$ Rajanpur, KSR $=$ Kasoor, $\mathrm{MZG}=$ Muzaffargarh, $\mathrm{PPN}=$ Pakpattan, $\mathrm{MLT}=$ Multan, and GJR $=$ Gujrat.

standard mixture. Limits of detection for Asp, Glu, Leu, Arg, and His were $3.4,10.3,6.8,10.8$, and 9.7 whereas the limits of quantification for the respective amino acids were found to be $10.2,31.3,20.5,32.8$, and $29.3 \mathrm{ng} / \mathrm{mL}$. Distribution of amino acids in wheat sample is represented in Table 4.

Aspartic acid, an excitatory neurotransmitter, is a metabolite in the urea cycle and helps in the removal of ammonia [14]. Aspartic acid was found to be maximum in NRW while minimum in VHR, that is, 1.292 and $0.706 \mathrm{~g} / 100 \mathrm{~g}$ flour among samples collected from different districts, and it was found to be maximum in Ass-11 (0.198 g/100 g flour) and minimum in FD-08 $0.182 \mathrm{~g} / 100 \mathrm{~g}$ flour among the wheat hybrids.

Glutamic acid performs a critical role in brain disorders such as Parkinson disease, schizophrenia, and epilepsy and also helps in correcting behavioral disorders of childhood.
Its concentration was highest in RJP $1.292 \mathrm{~g} / 100 \mathrm{~g}$ flour and lowest in VHR $0.706 \mathrm{~g} / 100 \mathrm{~g}$ flour. Wheat hybrids Pb-11 contained the maximum amount of glutamic acid, that is, $0.897 \mathrm{~g} / 100 \mathrm{~g}$ flour, and Seher-06 the minimum, $0.713 \mathrm{~g} / 100 \mathrm{~g}$ of flour.

Leucine, an essential amino acid, helps in the formation of sterols in adipose and muscle tissue. It stimulates the synthesis of muscle protein [6]. This amino acid has been maximized in RYK and minimized in NRW, that is, 0.6 and $0.339 \mathrm{~g} / 100 \mathrm{~g}$ flour, respectively. $\mathrm{Pb}-11$ contained the maximum, that is, $0.484 \mathrm{~g} / 100 \mathrm{~g}$ flour, and FD-08 the minimum, $0.335 \mathrm{~g} / 100 \mathrm{~g}$ of flour.

Arginine, owing to its NO-stimulating effects, finds applications in therapeutic regimens for congestive heart failure, angina pectoris, hypertension, preeclampsia, and coronary heart disease. Arginine was found to be maximum 
in BWP $(0.662 \mathrm{~g} / 100 \mathrm{~g}$ of flour $)$ while minimum in $\mathrm{MZG}$ $(0.14 \mathrm{~g} / 100 \mathrm{~g}$ of flour $)$. Ass-11 contained the maximum, that is, $0.895 \mathrm{~g} / 100 \mathrm{~g}$ flour, and FD-08 the minimum, $0.118 \mathrm{~g} / 100 \mathrm{~g}$ of flour.

Histidine is an indispensable amino acid that helps in regulating $\mathrm{pH}$ values of blood, growth, and natural repairment. Histidine was present in maximum concentration in SHW ( $0.377 \mathrm{~g} / 100 \mathrm{~g}$ flour) while in minimum concentration in GJW ( $0.088 \mathrm{~g} / 100 \mathrm{~g}$ flour). Ass-11 contained the maximum of histidine $(0.266 \mathrm{~g} / 100 \mathrm{~g}$ flour $)$ while $\mathrm{Pb}-11$ contained the minimum.

Wheat flour representative sample of ration from local market was found to have Asp $(0.199 \mathrm{~g} / 100 \mathrm{~g}$ flour $)$, Glu (0.812 g/100 g flour), Leu (0.321 g/100 g flour), Arg (0.5 g/100 g flour), and His (0.139 $\mathrm{g} / 100 \mathrm{~g}$ flour).

The amino acids were found to vary as follows: aspartic acid 0.130-0.496, glutamic acid 0.706-1.292, leucine 0.3210.6 , arginine $0.118-0.895$, and histidine $0.088-0.377 \mathrm{~g} / 100 \mathrm{~g}$ flour.

The reported values of the amino acids in $\mathrm{g} / 100 \mathrm{~g}$ flour by Anjum et al. were found to vary as follows: aspartic acid 0.453-0.841, glutamic acid 0.743-1.313, leucine 0.449-0.927, arginine 0.149-0.643, and histidine 0.1180.265 . The results of Boila et al. were aspartic acid $0.772 \mathrm{~g} / 100 \mathrm{~g}$, glutamic acid $5.68 \mathrm{~g} / 100 \mathrm{~g}$, leucine $1.04 \mathrm{~g} / 100 \mathrm{~g}$, arginine $0.695 \mathrm{~g} / 100 \mathrm{~g}$, and histidine $0.352 \mathrm{~g} / 100 \mathrm{~g}$, whereas Tanacs et al. tested two wheat varieties and reported that wheat contained aspartic acid $0.250 \mathrm{~g} / 100 \mathrm{~g}$, glutamic acid $2.96 \mathrm{~g} / 100 \mathrm{~g}$, leucine $0.574 \mathrm{~g} / 100 \mathrm{~g}$, arginine $0.270 \mathrm{~g} / 100 \mathrm{~g}$, and histidine $0.112 \mathrm{~g} / 100 \mathrm{~g}$. This variation can be attributed to the differences in the genetic makeup of wheat cultivars and a type of wheat, that is, soft, medium, or hard $[2,20,22]$.

There occurred a vast variety of the detected amino acids in the samples. The results of the present study lied close to the reported literature. The variation in amino acid content can also be attributed to the change in environment and climatic conditions at the time of ripening.

\section{Conclusion}

A RP-HPLC-FLD precolumn derivatization with OPA-2mercaptoethanol has been developed for the estimation of amino acids in wheat samples. The proposed method is rapid, simple, accurate, and precise and all these factors render this method suitable for routine analysis of large numbers of cereals. The average values for aspartic acid, glutamic acid, leucine, arginine, and histidine were $0.253,0.907,0.446,0.374$, and $0.181 \mathrm{~g} / 100 \mathrm{~g}$ flour, respectively. Maximum values for aspartic acid, glutamic acid, leucine, arginine, and histidine were found in samples collected from VHR, RJP, RYK, BWP, and NRW, respectively, whereas the minimum in NRW, VHR, NRW, MZG and RYK respectively. Wheat variety $\mathrm{Pb}-$ 11 contained a maximum concentration of aspartic acid, glutamic acid, and leucine whereas Ass-11 contained arginine and histidine in maximum amount. The FD- 08 contained the least amount of aspartic acid and leucine while $\mathrm{Pb}-11$ was deficient in arginine and histidine.

\section{Conflict of Interests}

The authors declare that there is no conflict of interests regarding the publication of this paper.

\section{Acknowledgment}

The authors are grateful for the technical assistance provided by the Quality operation laboratory, University of Veterinary and Animal Sciences, Pakistan.

\section{References}

[1] H. D. Belitz, W. Grosch, and P. Schieberle, Food Chemistry, Springer, New York, NY, USA, 4th edition, 2009.

[2] F. M. Anjum, I. Ahmad, M. S. Butt, M. A. Sheikh, and I. Pasha, "Amino acid composition of spring wheats and losses of lysine during chapati baking," Journal of Food Composition and Analysis, vol. 18, no. 6, pp. 523-532, 2005.

[3] J. D. Kopple and M. E. Swendseid, "Evidence that histidine is an essential amino acid in normal and chronically uremic man," The Journal of Clinical Investigation, vol. 55, no. 5, pp. 881-891, 1975.

[4] J. D. Kopple and M. E. Swendseid, "Effect of histidine intake on plasma and urine histidine levels, nitrogen balance and $\mathrm{N} \tau$ methylhistidine excretion in normal and chronically uremic men," Journal of Nutrition, vol. 111, no. 6, pp. 931-942, 1981.

[5] E. S. Cho, H. L. Anderson, R. L. Wixom, K. C. Hanson, and G. F. Krause, "Long-term effects of low histidine intake on men," Journal of Nutrition, vol. 114, no. 2, pp. 369-384, 1984.

[6] J. Rosenthal, A. Angel, and J. Farkas, "Metabolic fate of leucine: a significant sterol precursor in adipose tissue and muscle," American Journal of Physiology, vol. 226, no. 2, pp. 411-418, 1974.

[7] D. K. Layman, "The role of leucine in weight loss diets and glucose homeostasis," The Journal of Nutrition, vol. 133, no. 1, pp. 261S-267S, 2003.

[8] World Health Organization, "Protein and amino acid requirements in human nutrition: report of a joint $\mathrm{FAO} / \mathrm{WHO} / \mathrm{UNU}$ expert consultation," Tech. Rep. Series no. 935, World Health Organization, Geneva, Switzerland, 2002.

[9] S. F. Abcouwer and W. W. Souba, "Glutamine and arginine," in Modern Nutrition in Health and Disease, M. E. Shils, J. A. Olson, M. Shike, and A. C. Ross, Eds., pp. 559-569, Williams \& Wilkins, Baltimore, Md, USA, 9th edition, 1999.

[10] R. F. Knopf, J. W. Conn, S. S. Fajans, and et al, "Plasma growth hormone response to intravenous administration of amino acids," The Journal of clinical endocrinology and metabolism, vol. 25, pp. 1140-1144, 1965.

[11] T. Merimee, D. Lillicrap, and D. Rabinowitz, "Effect of arginine on serum-levels of human growth-hormone," The Lancet, vol. 286, no. 7414, pp. 668-670, 1965.

[12] R. Sapolsky, Biology and Human Behavior: The Neurological Origins of Individuality, The Teaching Company, 2nd edition, 2005.

[13] Third National Health and Nutrition Examination Survey (NHANES III), "NHANES III Combination foods data file from the dietary recall documentation," Series 11, No. 2A, April 1998.

[14] P. E. Chen, M. T. Geballe, P. J. Stansfeld et al., "Structural features of the glutamate binding site in recombinant NR1/NR2A $\mathrm{N}$-methyl-D-aspartate receptors determined by site-directed 
mutagenesis and molecular modeling," Molecular Pharmacology, vol. 67, no. 5, pp. 1470-1484, 2005.

[15] S. Wahab, S. Khan, M. K. Khattak, N. Ahmad, and F. Habib, "Nutritional qualities of different wheat," Sarhad Journal of Africulture, vol. 23, no. 4, pp. 1131-1136, 2007.

[16] M. A. Khan, I. A. Rana, and I. Ullah, "Nutritional evaluation of some commercial wheat varieties grown in Pakistan," Plant Foods for Human Nutrition, vol. 37, no. 3, pp. 253-260, 1987.

[17] M. A. Khan and B. O. Eggum, "Effect of baking on the nutritive value of Pakistani bread.," Journal of the Science of Food and Agriculture, vol. 29, no. 12, pp. 1069-1075, 1978.

[18] M. Iqbal, M. Azeem Khan, and M. Ahmad, "Adoption of recommended varieties: a farm-level analysis of wheat growers in irrigated Punjab," Pakistan Development Review, vol. 41, no. 1, pp. 29-48, 2002.

[19] M. Rubin, D. R. Schoonouer, and E. H. Bossard, "Amino acid profiles of corn and soybean meal by a modified analysis technique," Poultry Science Journal, vol. 54, no. 5, p. 1811, 1975.

[20] R. J. Boila, S. C. Stothers, and L. D. Campbell, “The relationships between the concentrations of individual amino acids and protein in wheat and barley grain grown at selected locations throughout Manitoba," Canadian Journal of Animal Science, vol. 76, no. 2, pp. 163-169, 1996.

[21] J. Greene, J. W. Henderson, and J. P. Wikswo, "Rapid and precise determination of cellular amino acid flux rates using HPLC with automated derivatization with absorbance detection," Application Note Pharmaceutical, Food Industries, Agilent Technologies.

[22] L. Tanács, J. Matuz, T. Bartók, and L. Gero, "Effect of NPK fertilisation on the amino acid composition of wheat grain yields," Novenytermeles, vol. 46, no. 1, pp. 43-51, 1997. 

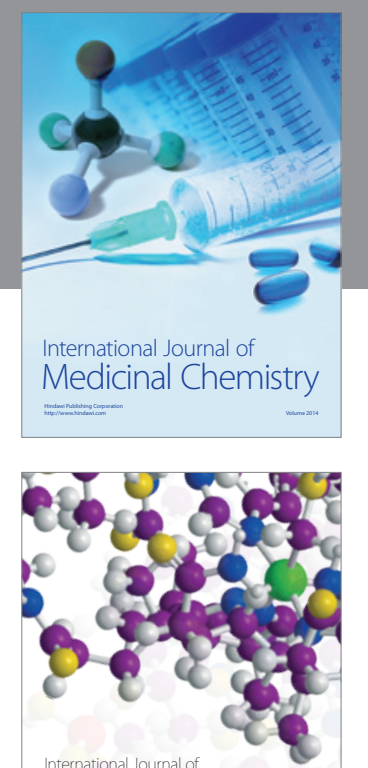

\section{Carbohydrate} Chemistry

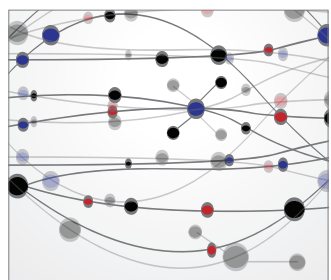

The Scientific World Journal
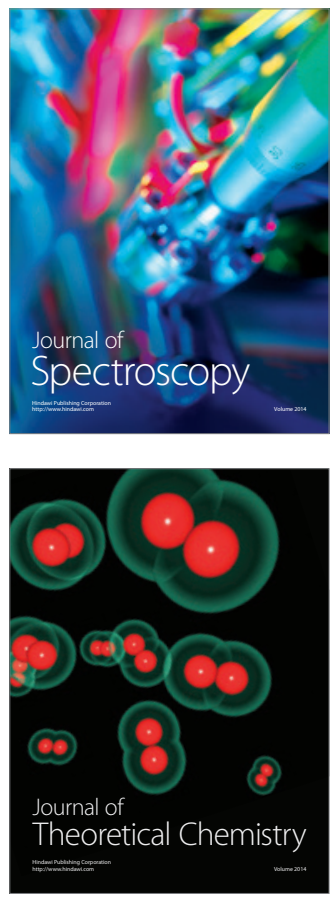
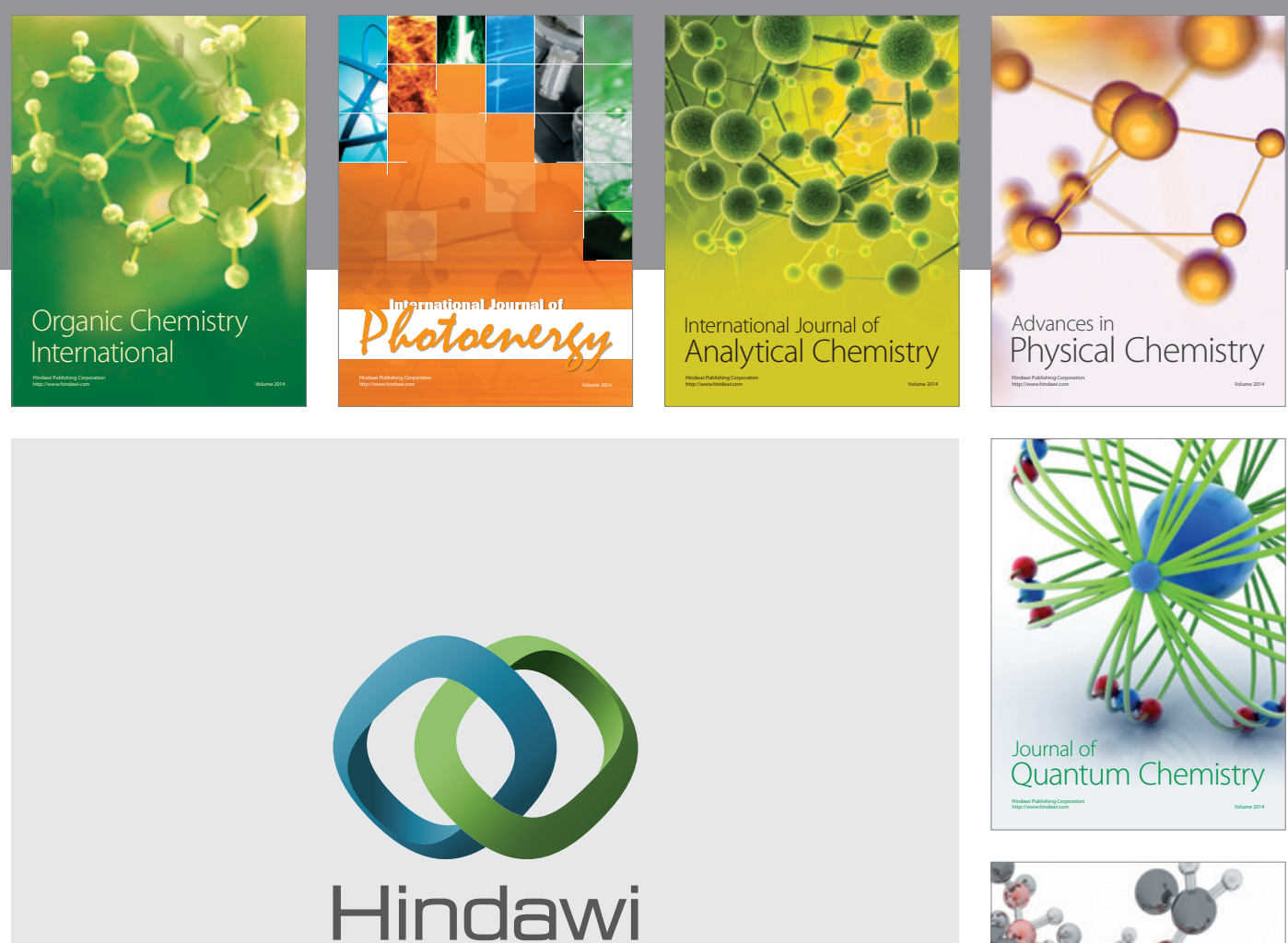

Submit your manuscripts at

http://www.hindawi.com

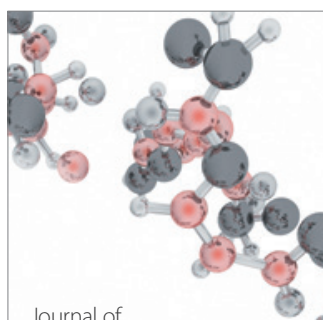

Analytical Methods

in Chemistry

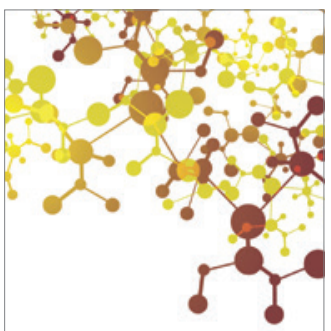

Journal of

Applied Chemistry

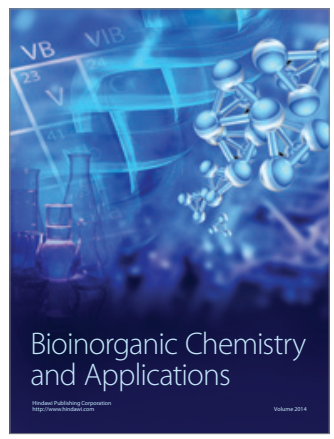

Inorganic Chemistry
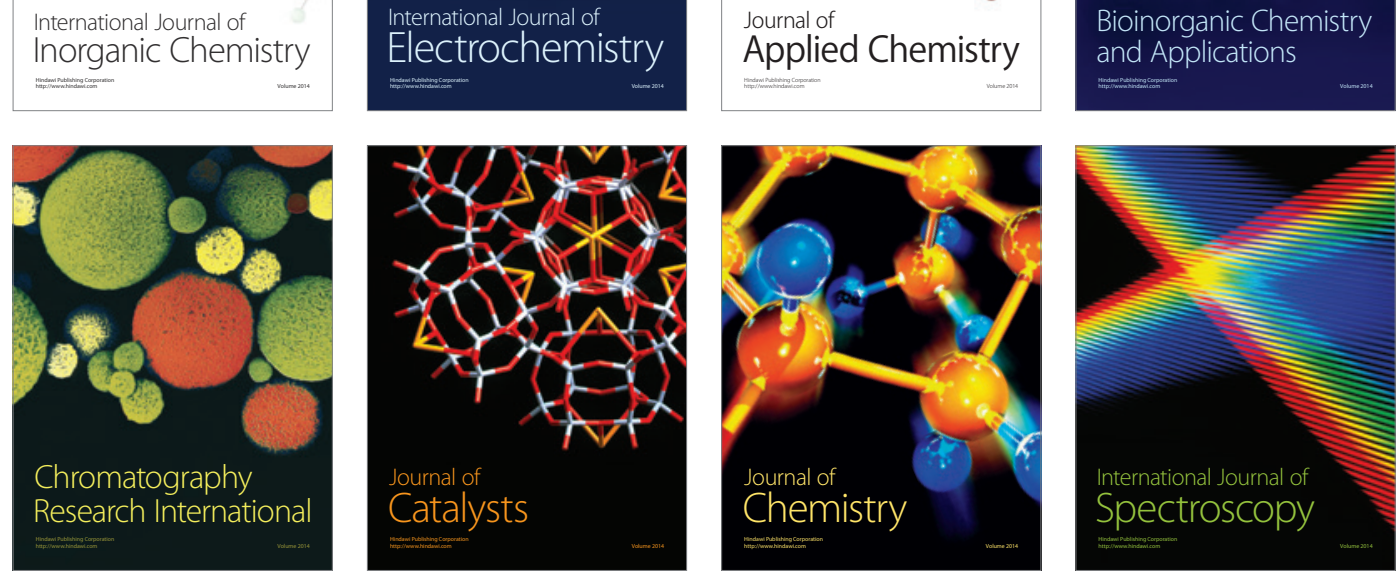